MARYAM AfRAKHTEH

AIDA MOEINI

MORTEZA SANeI TAHERI ${ }^{2}$

HAMID ReZA HAGHIGHATKHAH ${ }^{2}$

Original Article

Keywords

Placenta

Fetal development

Birth weight

Ultrasonography

Palavras-chave

Placenta

Desenvolvimento fetal

Peso ao nascer

Ultrassonografia

\section{Correlation between placental thickness in the second and third trimester and fetal weight}

\author{
Correlação entre a espessura da placenta \\ no segundo e terceiro trimester e peso fetal
}

Abstract

PURPOSE: To investigate relationship between placental thickness during the second and third trimesters and placental and birth weights. METHODS: From January 2011 to June 2012, a total of 250 singleton pregnant women presented at our antenatal clinic were enrolled in this prospective study. All recruited women were assessed at the $1^{\text {st }}$ trimester screening for baseline demographic and obstetric data. The placental thickness was measured trans-abdominally by placing the ultrasound transducer perpendicularly to the plane of the placenta, in the area of the cord insertion at second and third trimester. Pearson's correlation analysis was used to establish the degree of relationship between placental thickness and birth and placental weights. RESULTS: Of 250 recruited participants, 205 women were able to complete the study. The mean age of cases was $26.4 \pm 5.1$. Values of mean birth and placental weights were $305.56 \pm 657.0$ and $551.7 \pm 104.8$ grams respectively. Ultrasonographic measures of placental thickness in second and third trimester and changes between them were $21.68 \pm 4.52,36.26 \pm 6.46$ and $14.67 \pm 5.67 \mathrm{~mm}$ respectively. There was a significant positive correlation between placental thickness and birth weight in the second and third trimesters ( $r=0.15, p=0.03 ; r=0.14, p=0.04$ correspondingly). CONCLUSION: According to our study, birth weight has a positive relation with both second and third trimester placental thickness; however, placental thickness change could not predict low birth weight.

\section{Resumo}

OBJETIVO: Investigar a relação entre espessura da placenta no segundo e terceiro trimestre e peso ao nascer e da placenta. MÉTODOS: Um total de 250 gestantes portadoras de um feto único que atenderam nossa clínica pré-natal de janeiro a junho de 2012 foram incluídas no estudo. Todas as mulheres recrutadas foram avaliadas na triagem do $1^{\circ}$ trimestre a respeito dos dados demográficos e obstétricos basais. A espessura da placenta foi medida transabdominalmente colocando-se o transdutor do ultrassom perpendicular ao plano da placenta, na área de inserção do cordão, no segundo e terceiro trimestre. A análise de correlação de Pearson foi utilizada para estabelecer o grau de relação entre a espessura da placenta e o peso ao nascer e da placenta. RESULTADOS: Entre as 250 participantes recrutadas, 205 conseguiram completar o estudo. A média de idade das mulheres foi de 26,4 $\pm 5,1$ anos. $\bigcirc$ peso

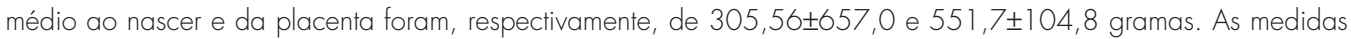
ultrassonográficas da espessura da placenta no segundo e terceiro trimestre e as mudanças entre eles foram,

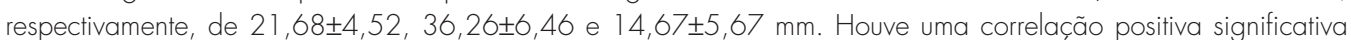
entre a espessura da placenta no segundo e terceiro trimestre e o peso ao nascer $(r=0.15, p=0.03 ; r=0.14$, $\mathrm{p}=0.04)$. CONCLUSÃO: Com base em nosso estudo, o peso ao nascer tem correlação positiva com a espessura da placenta tanto no segundo como no terceiro semestre; entretanto, a espessura da placenta não pode predizer baixo peso ao nascer.
Correspondence

Aida Moeini, M.D.

Department of Obstetrics and Gynecology

Tajish Hospital

Tairish Sq, Tehran, Iran

Received

$06 / 18 / 2013$
'Department of Obstetrics and Gynecology, Tajish Hospital, Shahid Beheshti University of Medical Sciences - Tehran, Iran. 2Department of Radiology, Tajish Hospital, Shahid Beheshti University of Medical Sciences - Tehran, Iran.

Conflict of interests: none. 


\section{Introduction}

The human placenta develops with the principal function of providing nutrients and oxygen to the fetus ${ }^{1}$. Adequate fetal growth and subsequent normal birth weight depends on the efficient delivery of nutrients from the mother to the fetus via normally functioning uteroplacental organ ${ }^{2}$. It is clear that normal development of placenta during gestation is necessary for supporting of a healthy fetus ${ }^{3}$. On the other hand, any impairment in its development may have a profound impact on fetal development and pregnancy outcome ${ }^{1}$. The ratio of the birth weight to the placental weight has been used since the 1940 s as an index for the appropriateness of fetal growth ${ }^{4}$.

The definitive placenta is clearly visible on ultrasound from approximately 9-10 weeks of gestation, when it demonstrates a uniformly granular echogenic pattern ${ }^{5}$. Ultrasonography (US) enables the evaluation of the placenta and the detection of placental abnormalities using different parameters such as placental thickness and volume or especial techniques like three-dimensional (3D) power Doppler ${ }^{6-10}$. Recent studies focused on 3D measurement of placenta to predict the adverse pregnancy outcome; however, this technique is relatively new, needs complex clinical setting and gives conflicting results regarding its reproducibility in evaluating placenta ${ }^{1}$. Ultrasound measurement of placental thickness is a relative simple, reproducible and clinical useful way, which had been used for more than two decades ${ }^{6-8}$.

Some investigators showed in two different studies that placental size in mid-pregnancy independently has relationship with birth parameters ${ }^{9,10}$; although most of the placental growth occurred in the third trimester. Other researchers like Goldenberg et al. ${ }^{11}$ stated that birth size was only predicted in the third trimester by fetal ultrasound measurements. Many studies were retrospective or cross-sectional in design and could not truly show the relationship between placental measurements and fetal outcome ${ }^{6,10}$. It seems reasonable that serial evaluation of placental thickness in second and third trimester could help to determine normal development and functional placenta and deserve as a good predictor of fetal growth and birth weight.

The aim of this prospective longitudinal study was to investigate the relationship between placental thickness during the second and third trimesters and placental and birth weights.

\section{Methods}

A total of 250 pregnant women aged between 15 and 45 years presented at our antenatal clinic of Tajrish Hospital were enrolled in a prospective observational study from January 2011 to June 2012. The exclusion criteria were systemic illness or genetic abnormality, for example, sickle cell disease, morbid obesity, missing records and unwilling to incorporate in the study. All patients provided an informed written consent after they were fully instructed about the investigation. The study was approved by ethical committee of Shahid Beheshti University of Medical Sciences.

All recruited women were observed at the $1^{\text {st }}$ trimester screening at antenatal clinic and assessed for baseline demographic and obstetric data including age, parity, body mass index (BMI) and past medical events. Smoking, alcohol and drug use were also determined. At second and third trimester (15-20 and 30-34 weeks of gestation respectively), the maternal weight, weight gain, BMI, BMI gain and data of ultrasound examination were recorded. At the time of delivery after assessment of maternal weight as mentioned above, the birth weight (in grams), fetal sex, and mode of delivery were taken. After delivery, the placenta was weighed in grams as previously described by Azpurua et al. ${ }^{2}$. Fetal and neonatal status and morbidity including baby Apgar scores, fetal distress or fetal death and admission to the neonatal intensive care unit were also determined. All the examinations and data recording were performed by two senior resident physicians.

All pregnant women underwent ultrasound evaluation of placental thickness at the time of second trimester (15-20 weeks of gestation) as well as third trimester (30-34 weeks of gestation). All sonographic examinations were performed trans-abdominally using a Hitachi EUB 525 Color Doppler ultrasound scanner (Gyeonggi-do, South Korea) with a 3.5-MHz convex-array transducer. The placental thickness was measured by placing the ultrasound transducer perpendicularly to the plane of the placenta, in the area of the cord insertion, near the mid-placental portion as described by Hoddick et al. ${ }^{12}$. Each evaluation was performed by one of two experienced sonographers of our hospital with minimum inter- and intra-observer variability.

Results were given as mean plus or minus SD. Statistical analysis was performed using the SPSS 16.0 statistical software package (SPSS Inc., Chicago, IL, USA) using One-way ANOVA and one-way repeated measures ANOVA tests. Pearson's correlation analysis was used to establish the degree of relationship between placental thickness and birth and placental weights. $\mathrm{P}$ values of less than 0.05 were considered statistically significant.

\section{Results}

Of 250 recruited participants who fulfilled the entry criteria, 205 women were able to complete the study and their data were included in the final analyses. The mean age of the entire group was 26.4 45.1 (range 16 to 42 years). Table 1 provides a summary of the baseline characteristics of pregnant women at first visit. Thirty seven 
Table 1. Baseline characteristics of pregnant women at first visit

\begin{tabular}{|c|c|c|}
\hline Variables & $\mathrm{n}$ & $\%$ \\
\hline \multicolumn{3}{|l|}{ Gravity } \\
\hline 1 & 104 & 50.7 \\
\hline 2 & 65 & 31.7 \\
\hline 3 & 24 & 11.7 \\
\hline$\geq 4$ & 12 & 5.9 \\
\hline \multicolumn{3}{|l|}{ Parity } \\
\hline 0 & 130 & 63.4 \\
\hline 1 & 58 & 28.3 \\
\hline 2 & 12 & 5.9 \\
\hline$\geq 3$ & 5 & 2.5 \\
\hline \multicolumn{3}{|l|}{ Abortion } \\
\hline 0 & 157 & 76.6 \\
\hline 1 & 42 & 20.5 \\
\hline$\geq 2$ & 61 & 2.5 \\
\hline Mean weight \pm SD (kg) & \multicolumn{2}{|c|}{$63.4 \pm 8.0$} \\
\hline Mean height $\pm S D(\mathrm{~cm})$ & \multicolumn{2}{|c|}{$160.6 \pm 7.8$} \\
\hline Mean BMI $\pm S D\left(k g / \mathrm{m}^{2}\right)$ & \multicolumn{2}{|c|}{$19.8 \pm 3.1$} \\
\hline Mean FBS $\pm S D(m g / d l)$ & \multicolumn{2}{|c|}{$85.6 \pm 12.9$} \\
\hline
\end{tabular}

BMI: body mass index; FBS: fasting blood sugar; SD: standard deviation.

(18\%) mothers had history of previous disease including diabetes, hypertension, thyroid disease and infertility. Two cases of intrauterine fetal demise were occurred in the study group. No cases of hydrops fetalis or a specific infectious disease (syphilis, cytomegalovirus infection, toxoplasmosis, schistosomiasis) were reported.

Mean \pm SD of gestational age was $268.2 \pm 22.3$ days. Values of mean birth and placental weights were 3,051.5 \pm 657.0 and $551.7 \pm 104.8$ grams respectively. The percentage of macrosomia $(>4,000 \mathrm{~g})$ and low birth weight $(<2,500 \mathrm{~g})$ neonates at delivery were 2.5 and $14.6 \%$ respectively. The delivery mode was normal vaginal (NVD) in 121 women (59\%) and cesarean in 84 cases (41\%). Baby Apgar score of less than 3,3 to 7 and greater than 7 were observed in 4 (2\%), $19(9.3 \%)$ and $182(88.7 \%)$ newborns respectively.

Ultrasonographic measures of placental thickness in second and third trimester and changes between them were $21.6 \pm 4.5$ (range: $14.9-35 \mathrm{~mm}$ ), $36.2 \pm 6.4$ (range: $20-79 \mathrm{~mm}$ ) and $14.67 \pm 5.67 \mathrm{~mm}$ respectively. There was a significant positive correlation between placental thickness and birth weight in the second and third trimesters $(r=0.15, p=0.03 ; r=0.14, p=0.04$ correspondingly) (Figures 1 and 2). However, no correlation was observed with placental thickness change $(p=0.7)$. Placental weight did not correlate with both second and third trimester's placental thickness $(r=0.005, p=0.9 ; r=0.003, p=0.9$ respectively).

On the other hand, placental thickness change was related to mother's age, weight and height $(r=0.2, p=0.003$; $\mathrm{r}=0.16, \mathrm{p}=0.02 ; \mathrm{r}=0.14, \mathrm{p}=0.04$ respectively). As it can be observed in the Table 2, mothers with gestational age less than 36 weeks, age greater than 40 years, history

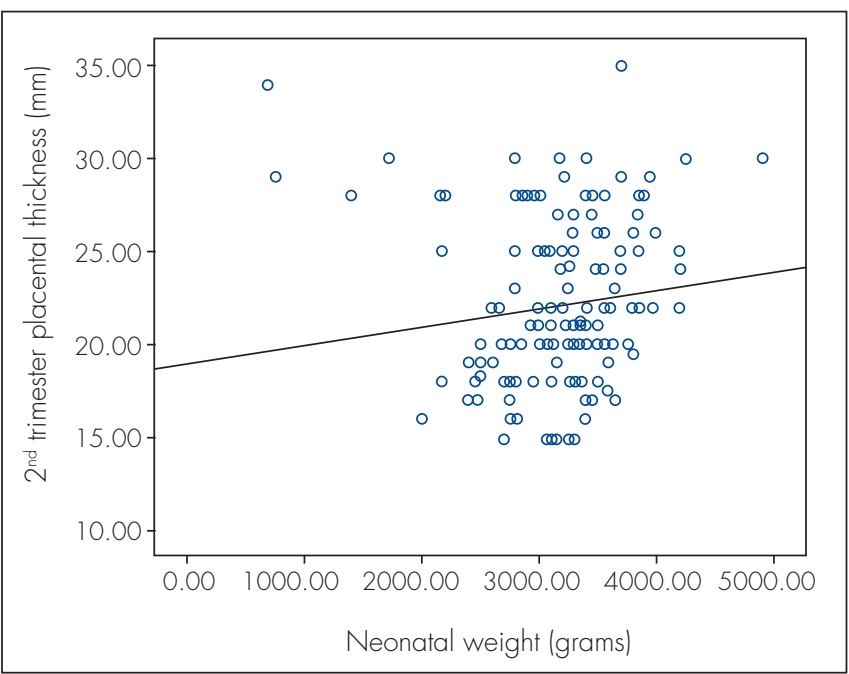

Figure 1. Scatter-plot illustrating the association between the placental thickness measured by ultrasound at second trimester and neonatal birth weight $(r=0.15, p=0.03)$

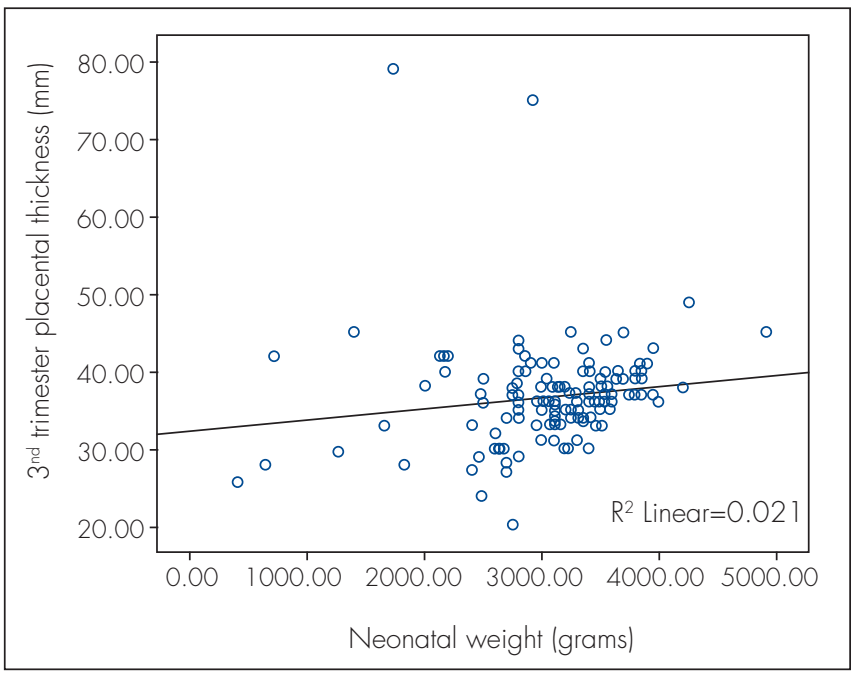

Figure 2. Scatter-plot illustrating the association between the placental thickness measured by ultrasound at third trimester and neonatal birth weight $(r=0.14, p=0.04)$

of diabetes or thyroid disease and suffering from ITP or preeclampsia had thicker placenta in the third trimester. This pattern was also observed for second trimester placental thickness but not for mother age. Placental thickness of second trimester were classified into 3 sub-groups of $\leq 17$, $17-27$ and $>27 \mathrm{~mm}$ (based on ROC-curve). Evaluation of birth weight in these sub-groups shows a significant lower birth weight in the thickest sub-group $(3,100.1 \pm 565.6 \mathrm{~g}$ in thickness of $\leq 17 \mathrm{~mm}, 3,176.6 \pm 626.1 \mathrm{gr}$ in thickness of $17-27 \mathrm{~mm}$ and $2,714.2 \pm 919.6 \mathrm{gr}$ in thickness of $>27 \mathrm{~mm}$ $[\mathrm{p}=0.005])$. Also, this pattern was observed in placental thickness of third trimester $(2,966.9 \pm 845.6 \mathrm{~g}$ in thickness of $\leq 30 \mathrm{~mm}, 3,195.8 \pm 410.5 \mathrm{gr}$ in thickness of $30-40 \mathrm{~mm}$ and $2,828.5 \pm 580.9 \mathrm{~g}$ in thickness of $>40 \mathrm{~mm} \mathrm{[p=0.001]).}$ 
Table 2. Labor characteristics and second and third trimester's placental thickness according delivery outcome data

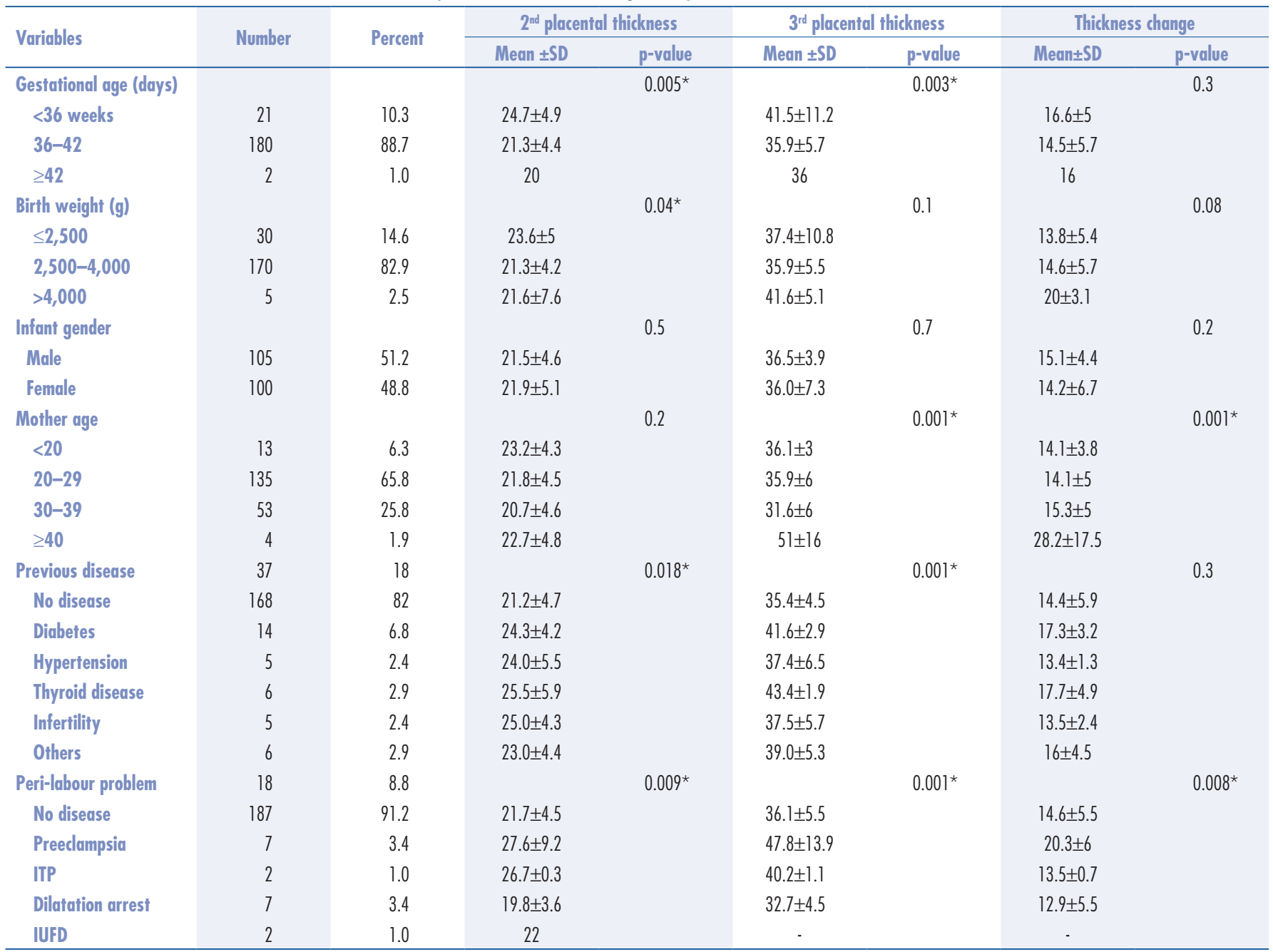

*Statically significant.

ITP: idiopathic thrombocytopenic purpura; IUFD: intrauterine fetal demise; SD: standard deviation.

\section{Discussion}

Several parameters were used to assess fetal growth in order to quantify intrauterine environmental adequacy and fetal well-being ${ }^{13-15}$. Normal placental function and structure is a necessary factor for the formation of a healthy fetus and consequently normal birth weight ${ }^{16}$. Early detection of any pathology in the placental bed and villi helps obstetrician to consider prenatal care precisely ${ }^{17}$. The rate of placental growth appears to be an important determinant of birth weight, with the rate between 17 and 20 weeks gestation being a predictor of fetal abdominal and head circumference, femoral length and biparietal diameter; weaker associations are observed for placental growth earlier in pregnancy ${ }^{18}$. Several aspects of placental growth including volume, weight, and plate area were investigated in different researches in order to find their correlation with fetal anthropometry ${ }^{2}$. For example, Clapp et al. ${ }^{9}$ evaluated placental growth of forty singleton pregnant women. They showed a significant correlation $(r>0.79)$ between second-trimester placental growth rate and birth weight ${ }^{9}$. In study of Kinare et al. ${ }^{10}$, mid-pregnancy placental volume was related to birth weight. Correlation of placental thickness with gestational age and fetal growth was also reported in a research by Karthikeyan et al. ${ }^{19}$. Sonographic measurement of placental thickness is a relative simple and clinical useful way to detect 'early warning signs' which could be done in any unequipped obstetrician center ${ }^{20}$. Cooley et al. ${ }^{21}$ suggested that antenatal ultrasound of the placenta may aid detection of placental disease. They showed the placental thickness in the second trimester was less in pregnant women complicated by chorioamnionitis ${ }^{21}$. Unfortunately, even sonologists make limited attention to placental thickness in their routine evaluation of pregnancy ${ }^{20}$. In a research held in Nigeria, significant positive correlation were found between placental thickness and estimated fetal 
weight in the second and third trimesters $(r=0.61$ and $r=0.57$ respectively) ${ }^{22}$.

In contrary to some other researches, our study evaluates both second and third trimester's placental thickness and their relationship with birth weight in a prospective longitudinal model. A weak but positive correlation between placental thickness and birth weight in the second as well as third trimesters was observed accordingly.

Many pathological conditions could induce placentomegaly a result of inflammation, edema, or compensatory hypertrophy ${ }^{6}$. This subject was observed in our cases, as mothers with gestational age less than 36 weeks, history of diabetes or thyroid disease and suffering from ITP or preeclampsia had thicker mean placenta in both trimesters. In a study by Elchalal et al. ${ }^{6}$ a linear increase of placental thickness was found to correlate with gestational age throughout pregnancy. They also showed a higher percentage of thick placenta in birth weight at term above $4,000 \mathrm{~g}$ or less than 2,500 g. However, they did not find any difference between patients with thick placenta and control group in terms of diabetes and hypertension. The authors insisted that increased placental thickness is not diagnostic of any specific disorder but may contribute to the management of a fetus at risk ${ }^{6}$. As it was shown in our study, patients with ITP or preeclampsia had thicker placenta in comparison with normal pregnant women. This observation was similar to the reports of previous studies ${ }^{23,24}$. Raio et al. ${ }^{25}$ stated that abnormally thick placentas have been correlated with adverse pregnancy outcome. Also, more frequent thick placentas in cases with absent end-diastolic umbilical arterial flow were found. It seems that intervillous perfused more slowly when the villous tree is too complex or too dense ${ }^{26}$. Recently, investigators are trying to increase detection rate of early sign for impaired placentation by combination of ultrasound findings with placental hormones such as human chorionic gonadotrophin (hCG), progesterone and pregnancy associated placenta protein A (PAPP-A $)^{1}$. Ultrastructural study of Macara et al. ${ }^{27}$ of placenta indicates that thickening of the basal lamina and increased deposition of collagen and laminin together with congestion of the capillaries by erythrocytes is the cause of limited oxygen transfer from the intervillous space to the growth retarded fetus. In a recent study, investigators proposed that sonographic increment of placental thickness during second trimester is due to over-inflation of the intervillous space by maternal blood rather than by adaptive formation of functional placental tissue ${ }^{28}$.

Definition of placentomegaly was different in various reports on the basis of gestational age, measurement technique and feto-maternal condition during pregnancy. Elchalal et al. ${ }^{6}$ defined a thick placenta (above $90^{\text {th }}$ percentile) as thicker than $35 \mathrm{~mm}$, when measured between 20 and 22 gestational weeks, and as thicker than $51 \mathrm{~mm}$ between 32 and 34 gestational weeks ${ }^{6}$. Dombrowski et al. ${ }^{24}$ used cut off at least $4 \mathrm{~cm}$ to diagnose thick placenta in a representative portion perpendicular to the chorionic plate. Habib ${ }^{16}$ used placental thickness of less than $2 \mathrm{~cm}$ at 36 weeks' gestation as a sensitive cut-off point for detecting low birth weight infants. A placental thickness more than $40 \mathrm{~mm}$ at term is associated with gestational diabetes, intrauterine infections and hydrops fetalis ${ }^{29}$. La Torre et al. ${ }^{30}$ opined that at no stage of pregnancy placental thickness exceeded $40 \mathrm{~mm}$ indirectly, thus indicating the cut off value for the upper limit. According to the present study, mother with placental thickness of more than $27 \mathrm{~mm}$ in second trimester and more than $37 \mathrm{~mm}$ in third trimester bear smaller babies. On the basis of the findings of this longitudinal research, it seems that using cut points for placental thickness can help obstetrician to predict newborn birth weight and identify the fetus in danger of being low birth weight. However, we realize that the study could have some weaknesses. The main bias is that the study has low number of patients. Hence, we recommend evaluation of these parameters with more subjects to find this cut point with more power.

\section{References}

1. Suri S, Muttukrishna S, Jauniaux E. 2D-ultrasound and endocrinologic evaluation of placentation in early pregnancy and its relationship to fetal birthweight in normal pregnancies and pre-eclampsia. Placenta. 2013 Jun 8. DOI: 10.1016/i.placenta.2013.05.003. [Epub ahead of print]

2. Azpurua H, Funai EF, Coraluzzi LM, Doherty LF, Sasson IE, Kliman M, et al. Determination of placental weight using two-dimensional sonography and volumetric mathematic modeling. Am J Perinatol. 2010;27(2):1515. DOI: $10.1055 / \mathrm{s}-0029-1234034$.
3. Salafia CM, Zhang J, Miller RK, Charles AK, Shrout P, Sun W. Placental growth patterns affect birth weight for given placental weight. Birth Defects Res Clin Mol Teratol. 2007;79(4):281-8.

4. Thomson AM, Billewicz WZ, Hytten FE. The weight of the placenta in relation to birthweight. J Obstet Gynaecol Br Commow. 1969;76(10):865-72.

5. Jauniaux $E$, Jurkovic $D$, Campbell $S$. In vivo investigations of anatomy and physiology of early human placental circulations. Ultrasound Obstet Gynecol. 1991;1(6):435-45. 
6. Elchalal U, Ezra Y, Levi Y, Bar-Oz B, Yanai N, Intrator O, Nadjari M. Sonographically thick placenta: a marker for increased perinatal risk - a prospective cross-sectional study. Placenta. 2000;21 (2-3):268-72.

7. Chen $M$, Leung KY, Lee CP, Tang MH, Ho PC. Placental volume measured by three-dimensional ultrasound in the prediction of fetal alpha (0)-thalassemia: a preliminary report. Ultrasound Obstet Gynecol. 2006;28(2): 166-72.

8. Hafner $E$, Metzenbauer M, Höfinger D, Munkel M, Gassner R, Schuchter $K$, et al. Placental growth from the first to the second trimester of pregnancy in SGA-foetuses and pre-eclamptic pregnancies compared to normal foetuses. Placenta. 2003;24(4):336-42.

9. Clapp JF 3rd, Rizk KH, Appleby-Wineberg SK, Crass JR. Secondtrimester placental volumes predicts birth weight at term. J Soc Gynecol Investig. 1995;2(1):19-22.

10. Kinare AS, Natekar AS, Chinchwadkar MC, Yajnik CS, Coyaji $\mathrm{KJ}$, Fall $\mathrm{CH}$, et al. Low midpregnancy placental volume in rural Indian women: a cause for low birth weight? Am J Obstet Gynecol. 2000; 182(2):443-8.

11. Goldenberg RL, Cliver SP, Neggers Y, Copper RL, DuBard MD, Davis RO, et al. The relationship between maternal characteristics and fetal and neonatal anthropometric measurements in women delivering at term: a summary. Acta Obstet Gynecol Scand. 1997; 165:8-13.

12. Hoddick WK, Mahony BS, Callen PW, Filly RA. Placental thickness. J Ultrasound Med. 1985;4(9):479-82.

13. Wolf $\mathrm{H}$, Oosting $\mathrm{H}$, Treffers PE. A longitudinal study of the relationship between placental fetal growth measured by ultrasonography. Am J Obstet Gynecol. 1989; 161 (5):1 140-5.

14. Hafner E, Philipp T, Schuchter K, Dillinger-Paller B, Philipp K, Baver P. Second-trimester measurements of placental volume by three-dimensional ultrasound to predict small-for-gestational-age infants. Ultrasound Obstet Gynecol. 1998;12(2):97-102.

15. Hoogland HJ, de Haan J, Martin CB Jr. Placental size during early pregnancy and fetal outcome: a preliminary report of a sequential ultrasonographic study. Am J Obstet Gynecol. 1980; 138(4):441-3.

16. Habib FA. Prediction of low birth weight infants from ultrasound measurement of placental diameter and placental thickness. Ann Saudi Med. 2002;22(5-6):312-4.

17. Tongsong T, Boonyanurak P. Placental thickness in the first half of pregnancy. J Clin Ultrasound. 2004;32(5):231-4.

18. Holroyd CR, Harvey NC, Crozier SR, Winder NR, Mahon PA, Ntani $G$, et al. Placental size at 19 weeks predicts offspring bone mass at birth: findings from the Southampton Women's Survey. Placenta. 2012;33(8):623-9. doi:10.1016/i.placenta.2012.04.007.
19. Karthikeyan T, Subramaniam RK, Johnson W, Prabhu K. Placental thickness \& its correlation to gestational age \& foetal growth parameters - a cross sectional ultrasonographic study. J Clin Diagn Res. 2012;6(10):1732-5. DOI:10.7860/JCDR/2012/4867.2652.

20. Harris RD, Cho C, Wells WA. Sonography of the placenta with emphasis on pathological correlation. Semin Ultrasound CT MR. 1996; 17(1):66-89

21. Cooley SM, Donnelly JC, Walsh T, McMahon C, Gillan J, Geary MP. The correlation of ultrasonographic placental architecture with placental histology in the low-risk primigravid population. J Perinat Med. 2013 Mar 21:1-5. DOI:10.1515/jpm-2013-0015. [Epub ahead of print]

22. Ohagwu CC, Abu PO, Ezeokeke UO, Ugwu AC. Relationship between placental thickness and growth parameters in normal Nigerian foetuses. Afr J Biotechnol. 2009;8(2):133-8.

23. Jauniaux E. Placental ultrasonographic measurement: what can we learn and is it worth doing routinely? Ultrasound Obstet Gynecol. 1992;2(4):241-2.

24. Dombrowski MP, Wolfe HM, Saleh A, Evans MI, O'Brien J. The sonographically thick placenta: a predictor of increased perinatal morbidity and mortality. Ultrasound Obstet Gynecol. $1992 ; 2(4): 252-5$.

25. Raio L, Ghezzi F, Cromi A, Nelle M, Dürig P, Schneider H. The thick heterogeneous (jellylike) placenta: a strong predictor of adverse pregnancy outcome. Prenat Diagn. 2004;24(3):182-8.

26. Nordenvall M, Ullberg U, Laurin J, Lingman G, Sandstedt B, Ulmsten U. Placental morphology in relation to umbilical artery blood velocity waveforms. Eur J Obstet Gynecol Reprod Biol. 1991;40(3):179-90

27. Macara L, Kingdom JC, Kaufmann P, Kohnen G, Hair J, More IA, et al. Structural analysis of placental terminal villi from growthrestricted pregnancies with abnormal umbilical artery Doppler waveforms. Placenta. 1996;17(1):37-48.

28. Porat S, Fitzgerald B, Wright E, Keating S, Kingdom JC. Placental hyperinflation and the risk of adverse perinatal outcome. Ultrasound Obstet Gynecol. 2013 Jan 3. doi:10.1002/uog. 12386. [Epub ahead of print]

29. Benirschke K, Kaufmann P. Pathology of human placenta. 4th ed. New York: Springer; 2000. Chapter 12: Anatomy and pathology of the umbilical cord and major foetal vessels; p. 335-98.

30. La Torre R, Nigro G, Mazzocco M, Best AM, Adler SP. Placental enlargement in women with primary maternal cytomegalovirus infection is associated with fetal and neonatal disease. Clin Infect Dis. 2006;43(8):994-1000. 